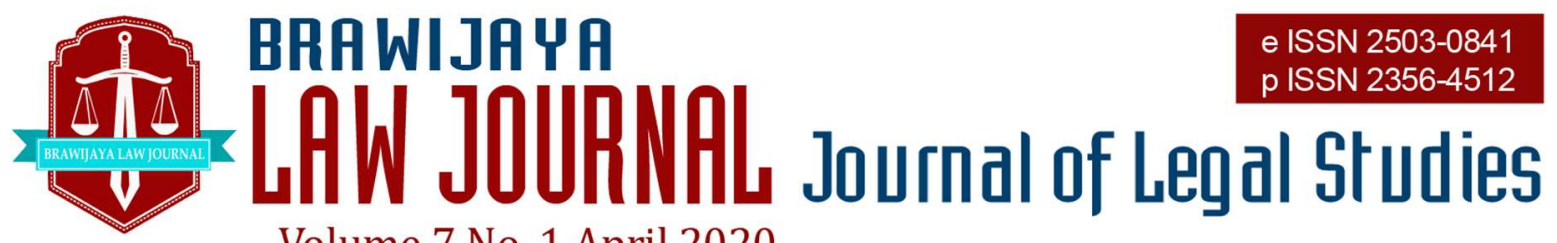

Volume 7 No. 1 April 2020

Nationally Accredited No. 30/E/KPT/2018 Dated 24th October 2018

This work is licensed under a Creative Commons Attribution-NonCommercial 4.0 International License

\title{
Governing Blockchain-Based Token in Indonesia: Legal and Technical Perspective
}

\section{Wahyu Yun Santoso a, Araya Anggara Putra ${ }^{b}$, Jonathan Hendson Passagic, Yoda Rifky Hanindya ${ }^{d}$, Annisa Azura Tagar ${ }^{\mathrm{e}}$}

\author{
${ }^{\mathrm{a} C e n t e r}$ for Law, Technology, RegTech \& LegalTech Studies / Universitas Gadjah Mada \\ Email: wahyu.yuns@ugm.ac.id \\ ${ }^{\mathrm{b} C e n t e r}$ for Law, Technology, RegTech \& LegalTech Studies / Universitas Gadjah Mada \\ Email: araya.anggara.p@ugm.ac.id \\ ${ }^{\mathrm{c} C e n t e r}$ for Law, Technology, RegTech \& LegalTech Studies / Universitas Gadjah Mada \\ Email: jonathan.hendson.p@ugm.ac.id \\ ${ }^{\mathrm{d}}$ Center for Law, Technology, RegTech \& LegalTech Studies / Universitas Gadjah Mada \\ Email: yoda.rifky.h@ugm.ac.id \\ ${ }^{\text {e}}$ Center for Law, Technology, RegTech \& LegalTech Studies / Universitas Gadjah Mada \\ Email: annisa.azura@ugm.ac.id
}

\section{Submitted : 2019-12-15 | Accepted : 2020-04-13}

\begin{abstract}
In the past decade, blockchain technology has caught the world's attention because of its disruptive nature in various industries. Along with blockchain adoption, blockchain-based token, or more popularly known as the "token," is widely used as a representation of a particular asset. In its development, blockchain innovators continue to encourage the birth of new tokens with more diverse attribution. From the regulator's point of view, the above gave rise to problems in the formation of regulations relating to tokens, mainly on its legality, whether token will determine as currency, securities, or commodity. If regulations still cannot catch up with the gap of technological advancement, this will hinder the development of blockchain technology in Indonesia.

The token regulatory framework has designed in several countries that have provided precise distinguishing characteristics for each type of token. However, in Indonesia, the absence of a clear and distinct definition of the types of tokens creates legal uncertainty for stakeholders. Therefore, this paper aims to give clarity to the legality of Blockchain-based tokens in Indonesia.
\end{abstract}

Keywords: law; blockchain; token; financial technology; Indonesia.

\section{INTRODUCTION}

In the past decade, blockchain technology has caught the world's attention because of its disruptive nature in various industries. ${ }^{1}$ This technology has recognized as the Fourth Industrial Revolution digital

\footnotetext{
Ito, J., Narula, N. and Ali, R. 'The Blockchain will do to the Financial System What the Internet Did to Media', Harvard Business Review, 2017. $<$ https://hbr.org/2017 /03/the-blockchain-will-do-
}

to-banks-and-law-firms-what-the-internet-did-tomedia?re ferral $=03758 \& \mathrm{~cm} \_v c=r r$ item_page.top_right $>$, accessed April 22019. 
wave drive ${ }^{2}$, blockchain has believed to bring breakthroughs to conventional financial, legal, and social patrons in $2025^{3}$. Blockchain's popularity was initiated by the presence of the Bitcoin digital currency in $2009^{4}$, in its development, Blockchain presents technological innovations that wider, - not only limited to virtual currency. ${ }^{5}$ One monumental innovation is the blockchainbased token, or more popularly known as the "token".

The description of tokens is not far from the literal definition, namely as "sign". ${ }^{6}$ Tokens are used as a "sign" on something digitally such as fiat money, coupons, smart property. ${ }^{7}$ This has intended to make the scarcity of digital assets in the blockchain. ${ }^{8}$ Ownership of these assets has broken down into token tokens. Besides the asset classes chosen, the use of tokens has practically applied in various use cases, including data management, intellectual property, and capital markets. ${ }^{9}$

The open-source blockchain technology continues to encourage the birth of new tokens with more diverse attribution. It has proven by the number of tokens, which in recent times has increased, not only limited to the number but also the complexity of how

2 Klaus Schwab, The Fourth Industrial Revolution, (World Economic Forum, Geneva, 2016), 23.

Ibid, page 143 .

4 Satoshi Nakamoto, Bitcoin: A Peer-to-Peer Electronic Cash System, $<$ https://bitcoin.org/bitcoin.pdf $>$, accessed April 1 2019.

5 Kaspars Zile and Renāte Strazdina, 'Blockchain Use Cases and Their Feasibility', (2018) 23(1) De Gruyter Open: Applied Computer Systems, ISSN 2255-8691 (online) ISSN 2255-8683 (print), doi: 10.2478/acss-2018-0002, 15.

6 Merriam-Webster, Defintion of token, $<$ https://www.merriam-

webster.com/dictionary/token>, acessed April 3 2019.

7 Vitalik Buterin, Ethereum Whitepaper, $<$ http://blockchainlab.com/pdf/Ethereum_white_p aper-

a next generation smart contract and decentral ized application platform-vitalik-buterin.pdf.>, accessed April 22019.

8 G. Miscione, R. Ziolkowski, L. Zavolokina, and G. Schwabe, 2018, 'Tribal Governance: The Business of Blockchain Authentication', (51st Hawaii International Conference on System Sciences (HICSS 2018) University of Hawai'i at Manoa the token has designed. From the regulator's point of view, the above gave rise to problems in the formation of regulations relating to tokens. On the other hand, if regulations still cannot catch up with the gap of renewable technology, this will hinder the perpetrators of technology. According to Deloitte's 2018 global blockchain survey, 39\% of respondents said the regulatory issue was a major obstacle to the development of blockchain technology in various sectors. ${ }^{10}$ Even worse, the regulator cannot present a legal umbrella in the event of excesses from the use of this technology.

The token regulatory framework has designed in several countries such as Singapore ${ }^{11}, \mathrm{UK}^{12}$, and Switzerland, ${ }^{13}$ which have provided clear distinguishing characteristics for each type of token. The terminology of the type of token used by each country varies, such as payment tokens, which have interpreted as virtual currency/cryptocurrency and token utilities that have equated with. However, in general, the token taxonomy regulatory framework distinguishes it into 3 (three) classifications: payment of tokens/ cryptocurrency, utility tokens, and tokenized security. ${ }^{14}$ In Indonesia, the existence of each type of token

2018-01-03 Hawaii, USA conference 51st Hawaii International Conference on System Sciences (HICSS 2018) ISBN: 978-0-9981331-1-9 In Proceeding).

9 Kaspars Zile and Renāte Strazdina, above n 5.

10 Deloitte, Breaking blockchain open: Deloitte's 2018 global survey, $<$ https://www2.deloitte.com/content/dam/Deloitte /us/Documents/financial-services/us-fsi-2018global-blockchain-survey-report.pdf.>, accessed 1 April 2019.

11 Money Authority of Singapore Guide to Digital Token Offerings.

12 Financial Conduct Authority United Kingdom, Guidance on Cryptoassets Consultation Paper CP19/3, < https://cdn.crowdfundinsider.com/wpcontent/uploads/2019/01/FCA-ConsultationGuidance-on-Cryptoassets-cp19-03.pdf>, accessed 2 April 2019.

13 Swiss Financial Market Supervisory Authority Guidelins for Enquiries Regarding The Regulatory Framework for Initial Coin Offerings.

14 Luis Oliveira, et.al., 'To Token or not to Token: Tools for Understanding Blockchain Tokens', (International Conference of Information Systems (ICIS 2018), San Francisco, USA, 12 December 
creates different legal consequences concerning securities law and overlapping governance. In responding to this matter, of course, the formation of legal instruments contributes in a comprehensive way to differentiate the types of tokens separately.

In Indonesia, several arrangements address the existence of tokens. The prohibition on the use of virtual currencies in this context - is equated with the terminology of payment tokens - as a payment instrument embodied in Bank Indonesia Regulation 18/40/PBI/2016 concerning Implementation of Payment Transaction Processing ("PBI 18/2016") and Bank Indonesia Regulation 19/12/PBI/2017 concerning the Implementation of Financial Technology ("PBI 19/2017"). For the use of tokens in the financial sector, this has regulated by the Financial Services Authority Regulation 13/POJK.02/2018 concerning Digital Financial Innovation in the Financial Services Sector ("POJK 13/2018"). In terms of token trading, based on the Regulation of Minister of Trade Number 99 the Year 2018 concerning General Policy for Futures Trading of Crypto Asset which raises "crypto-asset" as a commodity in Indonesia, there has been an Indonesia Commodity Futures Trading Supervisory Body ("BAPPEBTI") Regulation Number 5 the Year 2019 concerning Technical Provision of The Crypto Asset Physical Market in Futures Exchange ("BAPPEBTI Regulation 5/2019") explicitly generalizes tokens as one of the Crypto Asset forms which made as derivative of the coin. ${ }^{15}$ The existence of several arrangements above has shown how Indonesian legal politics address the existence of tokens in Indonesia. However, the absence of a clear and distinct definition of the types of tokens creates legal uncertainty for stakeholders.

$2018 \quad-16 \quad$ December 2018), https://doi.org/10.5167/uzh-157908, 9.

15 Article 1 (13) Indonesia Commodity Futures Trading Supervisory Body Regulation Number 5 Year 2019 concerning Technical Provision of The Crypto Asset Physical Market in Futures Exchange.

16 Article 6 (b) Law Of The Republic Of Indonesia Number 21 Year 2011 Concerning Financial
For example, if several business actors trade tokens with tokenized security characteristics, then with an effect basis, of course, this is the authority of the Financial Services Authority to supervise them. ${ }^{16}$ However, in the BAPPEBTI Regulation $5 / 2019$ that generalizes the definition of tokens as Crypto Asset will result in the overlapping authority of the two institutions in overseeing the existence of tokenized security. Also, it relates to the definition of tokens contained in the BAPPEBTI Regulation 5/2019 defining tokens as derivatives of the coin. The distinction in BAPPEBTI Regulation 5/2019 directly separates token and coin in a subordinate relationship. From a technical and practical perspective, "token" and "coin" are the same things because both can stand on their blockchain configuration, but on a case-bycase basis, they also can be distinguished by their characteristics-which are not always having a mutually exclusive feature. There is a possibility that both coin and token are a unit, which by The Swiss Financial Market Supervisory Authority (FINMA) has known as "hybrid token". ${ }^{17}$

On the other hand, reflecting on the token arrangement in the US, the existence of a token type differentiating legal instrument also has the potential to present new problems. At present, the US generalizes all types of tokens that are issued as "digital assets" and must meet securities law obligations. After that, in December 2018, the US congress filed Bill H.R 7356 to form a special arrangement for the taxonomy of tokens through the Taxonomy Act Token. In the Token Taxonomy Act draft, the US excludes the token utility as part of securities. ${ }^{18}$ Making explicit exceptions is a very dangerous form of policy because it would allow any "digital assets" that meet the basic technical standards above to fully

Services Authority State Gazette Of The Republic Of Indonesia Number 5253.

17 Swiss Financial Market Supervisory Authority Guidelins for Enquiries Regarding The Regulatory Framework for Initial Coin Offerings, page 2.

18 US Congress, H.R.7356-Token Taxonomy Act, $<$ https://www.congress.gov/bill/115thcongress/house-bill/7356/text $>$, accessed 1 Apri 2019. 
exclude from compliance as securities obligations and related investor protection.

Departing from the above issues, the establishment of legal instruments that specifically regulate the taxonomy of tokens in Indonesia becomes urgent. For blockchain-based tokens to unfold their full potential about reinventing ownership in the digital realm, the technology needs to recognized as a legalized system capable of creating an objectively new ontological category. A new kind of thing that deserves its regulatory framework that reflects the unique affordances and constraints of blockchain technology. There is an urgency to examine how the ideal taxonomy of blockchain-based tokens is regulated in other countries comprehensively in terms of juridical and technical aspects. Also, it should underline the legal problems arising in regards to the status quo of blockchainbased token regulation in Indonesia

\section{LEGAL MATERIALS METHODS}

AND

This research is a combination of normative and empirical legal research. Normative legal research process to find legal rules, legal principles, and the doctrine of the law to address the legal issues at hand. ${ }^{19}$ Meanwhile, empirical research could define as research based on experimentation or observation (evidence). ${ }^{20}$ The research would not only comprise the theory, and legal principles, however, the research also would like to formulate suitable approaches to close the gap between existing national regulation and the unregulated environment of blockchain.

19 Theresia Anita Christiani. 'Normative and Empirical Research Methods: Their Usefulness and Relevance in the Study of Law as an Object', (3rd Global Conference on Business and Social Sciences-2015) (2016) 219 Procedia Social and Behavorial Sciences, doi: 10.1016/j.sbspro.2016.05.006,

$<$ https://www.sciencedirect.com/science/article/pi i/S1877042816300660>, 202.

20 Ibid.

21 Perianne Boring and Amy Davine Kim, 'Understanding Digital Tokens: Market Overviews and Proposed Guidelines for

\section{RESULT AND DISCUSSION Property Law}

The token has defined as units that are transferable that generated within a distributed network that the ownership of the units can track through the application of blockchain technology. ${ }^{21}$ Token may represent rights to an asset, payment or benefit, or could exchange for goods and services. ${ }^{22}$ However, due to its novelty, the Token itself still has no legal certainty whether it is a property or not, hence for Token to have legal certainty, we shall define Token as a property that may represent rights. In the full Article 499 of the Indonesian Civil Law Code states, "The law interprets as objects all goods and rights which can be the subject of property".

Whereas, from the aforementioned provision it can be interpreted that objects can be in the form of tangible goods and intangible goods. Aside from an economic perspective, the underlying purpose to define Token as a property is for a token to can be categorized as a commodity along with its legal certainty, so Indonesian investors or Token owners have a clear basis for them to hold the ownership of Token.

As a commodity, Token has the opportunity to be traded in futures trading due to high liquidity and market volatility, but beforehand it needs to be legally declared as a commodity and meet the requirements set by BAPPEBTI. ${ }^{23}$ As a property, Token could give the legitimacy of ownership, namely ownership rights. ${ }^{24}$ Ownership rights can obtain through the transference of Token. In which, the Token transfer has several ways that have mentioned in the Elucidation of Article 8 (2) Bank Indonesia Regulation

Policymakers and Practitioners', Token alliance $<$ https://digitalchamber.org/token-alliancepaper/ $>$

22 LPEA Young PE Leaders Legal, 'Security Tokens - Legal Aspects', Paper, Luxembourg Private Equity \& Venture Capital Association, Luxembourg.

23 Anissa Rahma Diasti, 'The Legal Standing Bitcoin as A Commodity and Chance of Bitcoin as A Commodity upon Futures Trading in Indonesia', Undergraduate Thesis, Universitas Gadjah Mada, Yogyakarta, p. ix.

24 Article 28 of the Civil Code. 
19/12/PBI/2017 concerning the Implementation of Financial Technology ("PBI 19/2017") that mention the transfer of Virtual Currency could be done through mining, purchasing, or rewarding and in the Elucidation of Article 34 (a) Bank Indonesia Regulation 18/40/PBI/2016 concerning Implementation of Payment Transaction Processing ("PBI 18/2016") mention several examples of Virtual Currency.

As explained above, we determine Virtual Currency as apart of Token archetypes. Therefore, the aforementioned definition of Virtual Currency could used as a basis to analyze how Token can transfer, namely, purchasing or rewarding. However, there are still no certain provisions that regulate specifically regarding the movability of Token whereas there is another perspective which states that the activities, which closely related to cryptocurrency are mining/staking, transacting, trading, and providing services. ${ }^{25}$ In this manner, we also indicate that in the future, there is still room for the development of the Token transfer mechanism. Hence, those issues will be discussed below in an orderly manner. First, we analyzed the Token according to its form and its movability. Second, we analyzed the way in obtaining Token ownership rights.

According to the definition of property stipulated in Article 499 of the Civil Code, property (zaak) is used in two meanings, namely first in the sense of tangible goods, the second is in the knowledge of intangible goods. Meaning that property (zaak) in the Civil Code perspective is not only tangible properties (goed) but also includes the understanding of intangible properties. $^{26}$

In line with the Civil Code, Subekti stipulates the broadest definition of property (zaak) as anything that can be entitled to a person. Meanwhile, in the narrow sense, the property is interpreted as objects that have an

25 Dimaz Ankaa Wijaya, Dony Ariadi Suwarsono, Cryptaxforensic, when Cryptocurrency, Taxation, and Digital Forensic Collide: An Overview of Indonesian Cryptocurrency Market.

26 Ibid, 14.

27 Rachmadi Usman, Hukum Hak Atas Kekayaan Intelektual, (PT Alumni, Bandung, 2003), 51. appearance, can be seen, and hold. Rahmadi Usman also mentioned the definitions of properties, in which properties could interpret into three. Those are as follows: ${ }^{27}$

1. Properties in a broad sense are all things that can be entitled to a person;

2. Properties in the narrow sense are objects which can be seen by the senses only;

3. Properties as legal objects.

According to Subekti's perspective, properties can be in a form of tangible properties and intangible properties, which also stipulated in Article 503 of the Civil Code. Whereas, referring to Rahmadi Usman's interpretation of properties, tangible and intangible properties, are properties in broad sense, meanwhile in a narrow sense only tangible property that can be classified as properties. Tangible properties are the property that can be captured with the five senses, which can also be interpreted as someone's wealth. ${ }^{28}$ If the word "property" is used in the sense of someone's wealth, it includes intangible properties that are not visible and cannot be captured with five senses ${ }^{29}$ that include rights, for example, the right to receivables or billing. ${ }^{30}$

The token can be categorized as an intangible property because Token meet the characteristics of an intangible property that is digital in its form without having any physical shape. ${ }^{31}$ In advance, BAPPEBTI governs Crypto Assets as an intangible property, in which Crypto assets are intangible commodities in the form of digital assets, using cryptography, peer-to-peer networks, and distributed ledgers, to manage the creation of new units, verify transactions, and secure transactions without interference from other parties. ${ }^{32}$ According to the determination of Crypto Asset by BAPPEBTI Token as one of the Crypto Asset has known as an intangible commodity. This

$\begin{array}{ll}28 & \text { Subekti, Pokok-Pokok Hukum Perdata, } \\ \text { (Intermasa, Jakarta, 1984), 60. } \\ 29 \\ \text { Anissa Rahma Diasti, above n 23, 46. } \\ 30 \text { Sri Soedewi Masjchoen Sofwan, Hukum Perdata: } \\ \text { Hukum benda, (Liberty, Yogyakarta, 1981). } \\ 31 \text { Anissa Rahma Diasti, above n. 23, 46. } \\ 32 \text { BAPPEBTI Regulation No. } 5 \text { Year 2019, Article } 1\end{array}$ (7) 
is because Tokens have created by developers that are used in the blockchain system. Blockchain itself is a system that records all the digital transactions made with Token. ${ }^{33}$ Hence, Token is impossible to be captured by five senses. Even though Token has no physical form, it can still be considered as property because the scope of property is not limited only to tangible properties that can be captured by five senses but also include intangible properties such as Token.

Other than the classifications of property according to its form, the property can also be divided based on its movability, namely movable and immovable properties concerning Article 504 of the Civil Code. Movable properties are property that, according to its nature, could move, which regulated under Article 505 of the Civil Code. In full the Article stipulates that: "Movable properties by their nature are those which are movable or can be moved". The token is constituted as movable properties concerning Article 505 of the Civil Code, where Token is movable or can be moved. However, the movement of Token is conducted digitally through the internet within the blockchain.

Therefore, it could understand that Token is an intangible property that is movable or could move through the utilization of the internet. Whereas the movability of Token has performed through the blockchain system, the blockchain system is a network formed by nodes or also known as "Miners" that conduct transactions and validate it by demonstrating a Proof-ofWork is a form of adding a block. ${ }^{34}$ A block is an encrypted collection of the transactions which acts as a guarantee whether or not the transactions have been executed and verified. Each block records the transactions as well as the associated related data. The transactions are protected by "digital signature", which

33 TechTerms, Blockchain, $<$ https://techterms.com/definition/blockchain>, Accessed 21 September 2019.

34 Gupta, Suyash \& Sadoghi, Mohammad. (2018). Blockchain Transaction Processing. 10.1007/9783-319-63962-8_333-1.

35 Gupta, Suyash \& Sadoghi, Mohammad, above n 34. has sent to the "public key," of the receiver and digitally signed using "private key" whereas every transaction conducted, the user has to prove the ownership of the "private key". Thus, every new block created will be added to the existing chain of the block which associated one block to another. ${ }^{35}$ Moreover, each blockchain data structure consists of a "hash"-linked chain of blocks ${ }^{36}$ which needed to solve a blockchain computation and to prevent double-spending to happen. ${ }^{37}$ To understand the mechanism of the blockchain system, hence the process will be illustrated in the figure below.

\section{Figure 1. The role of digital signature in blockchain transaction $^{38}$}

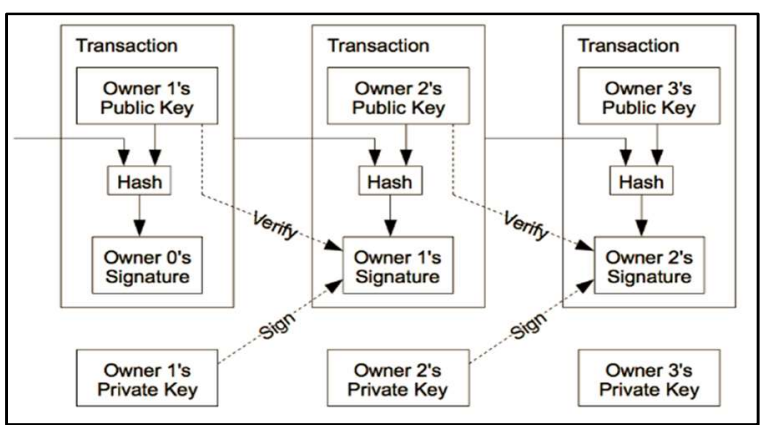

The figure above shows the transaction process in one of the Token protocols, Proofof-Work (PoW). In PoW, the user who sends Token also signs a hash from the previous transaction. After signing, the public key of the user receiving the coins has added at the end of the transaction. The recipient also participates in verifying the signature to prove the chain of ownership of the Token beforehand. This scheme is in line with the definition of "electronic coin," - in this paper it has likened to a Token - that is, "a chain of digital signatures". ${ }^{39}$ As for Miner, The Miner ensures that there is no "double-spent" an event where the Token switches more than

\footnotetext{
36 Morrissey, Erin, Breaking Down the Blockchain, $<$ https://medium.com/capital-one-tech/breakingdown-the-blockchain-f4b87422481b>, Accessed 2 October 2019.

37 Frankenfield, Jake, Hash, $<$ https://www.investopedia.com/terms/h/hash.asp $>$, Accessed 2 October 2019.

38 Satoshi Nakamoto, above n 4, 2.

39 Ibid.
} 
once in a transaction. ${ }^{40}$ This event provides an opportunity for Token owners to duplicate transactions on Tokens.

By referring to Article 499 of the Civil Code, a property requires that it can possess through ownership rights. In which, ownership rights in the legal order of properties have also known as eigendom rights. Token falls under property because it could own by a person or party. In which, a person or party could prove of owning Token after verifying the digital signature in the blockchain system. The receiving party of the digital currency then verifies the digital signature, which implies the ownership of several "private key", by using the "public key" of the sender on the respective transaction. For example, in insurance, assets that are uniquely identified by one or more identifiers and difficult to be destroyed or replicated can be registered in the blockchain. Thus, it can be used as proof to verify the ownership of an asset.

Token represents a property in the digital world ${ }^{41}$ that is obtained and stored electronically. The ownership rights can be transferred to another person or party whereas as mentioned under the BI Regulations, in full, the Elucidation of Article 8 (2) PBI 10/9/2017 states that:

Elucidation of Article 8 (2)

"Virtual currency" is digital money issued by parties other than monetary authorities obtained by mining, purchasing, or transfer of gifts (rewards). Prohibition of carrying out payment system activities using virtual currency because virtual currency is not a legal payment instrument in Indonesia."

This definition of virtual currency also stipulated in the Elucidation of Article 34 (a) PBI 19/2017, which states that:

40 Pilkington, Marc, '11 Blockchain technology: principles and applications.' (2016) 225 Research handbook on digital transformations, 252.

41 Tim Weingärtner, Tokenization of physical assets and the impact of IoT and AI, (Lucerne University of Applied Sciences \& Arts - School for Information Technology, Lucerne).

42 Press released, Bank Indonesia Memperingatkan Kepada Seluruh Pihak Agar Tidak Menjual,
Elucidation of Article 34 (a)

"Virtual currency" is digital money issued by parties other than monetary authorities obtained by mining, purchasing, or transfer of gifts (rewards) including Bitcoin, BlackCoin, Dash, Dogecoin, Litecoin, Namecoin, Nxt, Peercoin, Primecoin, Ripple, and Ven. Which not included in the definition of virtual currency is money electronic."

About the abovementioned articles of the BI Regulations, BI has mentioned several methods of virtual currency movability, which are through: (1) mining; (2) purchasing; or (3) transfer of gifts (rewards). Whereas according to Article 8 (2), BI prohibits the use of Token for the payment method in which Token is still not considered as a legal payment in Indonesia. In line with that, through the press release, BI clearly stated that Virtual Currency including Bitcoin, has not recognized as a legal payment instrument, therefore it is prohibited to be used as a payment instrument in Indonesia. ${ }^{42}$ It needs to underlined tha $\mathrm{t}$ virtual currency is not illegal, however only the transaction that is prohibited. This prohibition through BI Regulations aims to implement the precautionary principle, control the risk, and protect the users. ${ }^{43}$ Meanwhile, in Article 34 (a), it mentioned the examples of virtual currency which currently exists.

According to Sri Soedewi Masjchoen Sofwan, there are several characteristics of ownership rights, namely as follows: ${ }^{44}$

1. ownership rights are the parent rights to other property rights

2. ownership rights are the most complete rights 
3. ownership rights are permanent, meaning that they will not disappear from other property rights

4. ownership rights are the essence of other objects.

Ownership rights are regulated specifically under Article 570 of the Civil Code, which stated that:

"Ownership is the right to have
free enjoyment of property and to
dispose thereof absolutely,
provided that an individual does
not violate the laws of the public
ordinances stipulated by those
who have been granted authority
to do so, in the course of using
such properties, and provided
that an individual does not
interfere with other individuals
rights; the aforementioned shall
be without prejudice to
expropriation in the public
interest subject to the individual's
right to appropriate
compensation, pursuant to the
legal regulations."

According to Sri Soedewi Masjchoen Sofwan by referring to Article 570 of the Civil Code, ownership rights are the right to enjoy an object fully and to control the object freely, as long as it has not used contrary to the laws or general regulations held by an authority which has the authority to do so and as long as it does not cause interference with the rights of others; all of which do not reduce the possibility of revocation of that right in the public interest, with payment of appropriate compensation and according to the provisions of the law. ${ }^{45}$ Meaning that ownership rights are the most important rights when compared to other property rights because those who own it can fully enjoy and master it freely, meaning that the title of ownership rights cannot contest. ${ }^{46}$

Hence, based on the aforementioned, it can be concluded that the legal position of Token in the Civil Code is intangible movable property. The token is a property

45 Sri Soedewi Masjchoen Sofwan, above n. 30, 19

46 P.N.H. Simanjuntak, Pokok-Pokok Hukum Perdata Indonesia, (Penerbit Djambatan, Jakarta, 1999), 217. because it meets the requirements as property according to Article 499 of the Civil Code. As of Token is considered as property, it may also be entitled to the ownership rights as regulated under Article 570 of the Civil Code in which the property requires that it has possessed through the ownership rights.

It is worth noting how a transfer of ownership using Tokens takes place, whether it is legally permissible at all, and what effects this has on current jurisprudence. ${ }^{47}$ According to Book II of the Civil Code, the property has regulated with a closed regulatory system. This closed regulatory system means that a person or party cannot exercise or create new property rights, except those stipulated or determined by law. Meaning that a person or party can only impose by ownership rights concerning what has been stipulated by the law. ${ }^{48}$ Chapter Three Section One of Book II, specifically on Article 570 defines ownership as rights in enjoying and controlling properties, concerning Article 570 ownership rights in a broad sense could receive through recognition (toeeigening) or transfer (levering). ${ }^{49}$ Meanwhile, the ways to obtain ownership rights have regulated under Chapter Three Section Two, it has regulated under Article 584 of the Civil Code. Article 584 of the Civil Code, ownership rights over a property cannot obtain by other means, other than those stipulated in Article 584 of the Civil Code. Those are through ownership, attachment, expiration, inheritance, as well as appointment or surrender. In full Article 584 of the Civil Code stipulates as follows:

"Ownership rights over
properties cannot be acquired in
any manner other than by
ownership, because of
attachment: because it is expired,
because of inheritance, both
according to the law and
according to a will, and by
appointment or transfer pursuant
to a civil event to transfer
ownership, conducted by a

47 Tim Weingärtner, above n 41.

48 I Ketut Oka Setiawan, Hukum Perorangan dan Kebendaan, (Sinar Grafika, Jakarta, 2016), 105.

49 Anissa Rahma Diasti, above n 23. 
person who was entitled to act

freely towards the property."

From Article 584 of the Civil Code, the wording "cannot acquired in any manner other than $[\ldots]$ " limits the creation of new ownership rights aside from the law. ${ }^{50}$ Based on Article 584, the entitled person has the right to transfer ownership rights. Also, according to Article 613 of the Civil Code, it is stipulated that the transfer of the intangible property requires a record to show the ownership of that property. Hence, Token, as a digital asset that can be traded electronically and recorded, through the blockchain system has satisfied Article 613 of the Civil Code.

In regards to this paper, the process of transferring ownership rights of Token could finish through mining, purchasing/transacting, or rewarding activities as stipulated in BI Regulations. In which those processes are using blockchain systems whereas blockchain is interpreted as one type of distributed ledger technology ("DLT"). The big book contains information in the form of blocks. The block is connected in a data chain, not interrupted, and protected using cryptography. ${ }^{51}$ Blockchain has maintained by a peer-to-peer network made from a collection of nodes that have interconnected to one another. "Nodes" are the individual computers that have a complete copy of the blockchain database, which forwarding the transactions from one node to another. ${ }^{53}$ In the blockchain, there is

50 J. Satrio, 'Cara untuk Memperoleh Hak Milik Melalui Penyerahan', Hukum Online.com, 1 February 2018.< https://www.hukumonline.com/berita/baca/lt5a72 a1e93c48c/cara-untuk-memperoleh-hak-milikmelalui-penyerahan/>

51 Arvind Narayanan, et al., Bitcoin and Cyptocurrency Technologies: A Comprehensive Introduction, (Princeton University Press, Princeton, 2016), 38.

52 Ameer Rosic, What is Blockchain Technology? A Step-by-Step Guide for Beginners, <https://blockgeeks.com/guides/what-isblockchain-technology/>, Accessed 22 September 2019.

53 Anissa Rahma Diasti, above n 23, 22.

54 Ameer Rosic, above n 52.

55 Lam Pak Nian and David Lee Kuo Chen, 'Introduction to Bitcoin', dalam David Lee Kuo no longer one central server or a third party that controls the transaction, whereas there are several distributed and decentralized users. ${ }^{54}$ In which, the most commonly used blockchain system is a virtual currency. ${ }^{55}$ Therefore, as stipulated in the aforementioned BI Regulations the activity will be elaborated below:

\section{Mining}

The Cryptocurrency movement has always recorded on a blockchain, in which the data is then encrypted and distributed across the entire network. Before hence, the data shall go through a process called "Mining". The mining is a process in which transactions for various forms of cryptocurrency are verified and added to the blockchain digital ledger. ${ }^{56}$ Mining process involves "Miners" to compete to solve complicated mathematical problems that are associated with a block containing the transaction data. Miners have a function to update every time a transaction is made and also ensure the authenticity of the data. ${ }^{57}$ The winner between the Miners who compete to compute the mathematical questions can write the next block. Meaning, that Miners shall receive cryptocurrency as a reward for the success of resolving the cryptographic puzzle and adding a new block to the blockchain. ${ }^{58}$ The rewarding process for the work done by Miners is called Proof of Work. $^{59}$

Mining (claiming or toeeigening) is one of the Token interactions to obtain the

Chen, Handbook of Digital Currency: Bitcoin, Innovation, Financial Instruments and Big Data, (Elsevier Inc., Singapore, 2015), 12.

56 Forrest Stroud, cryptocurrency mining, $<$ https://www.webopedia.com/TERM/C/cryptocu rrency-mining.html $>$, Accessed 11 Septermber 2019.

57 Shanti Rexaline, Cryptocurrency Mining: What It Is, How It Works And Who's Making Money Off It, $<$ https://m.benzinga.com/article/9953629>, Accessed 19 September 2019.

58 Ethos, What are Cryptocurrency Miners? How does Cryptocurrency Mining work? https://www.ethos.io/what-are-minerscryptocurrency-mining, Accessed 19 September 2019.

59 Ibid. 
ownership rights of a Token. Miners, who can write the new block is entitled to the Token-based on Article 585 of the Civil Code. In full, Article 585 of the Civil Code states that: "Movable assets, which are not within an individual's ownership, shall become the property of the individual who shall be the first to appropriate them". Article 585 of the Civil Code, Mining activity has intended to obtain ownership rights over the movable properties which do not have possession. ${ }^{60} \mathrm{In}$ which in Mining, no users owning the Token in which the Tokens have received after adding a new block. Miners are getting paid for their works, and Miners motivated by the prize to reward as well as the rights to claim the Token as the fees paid by the cryptocurrency users. ${ }^{61}$ Therefore, it is legitimate to obtain Token through the mining process seeing that token is an intangible movable property that does not have possession.

\section{Purchasing or Transacting}

A transaction happens if there is a value transferred between the wallets that have entered into the blockchain. ${ }^{62}$ The wallets will issue address similar to a bank account number, which the addresses in the form of alphanumeric series of characters where the user can receive payment. ${ }^{63}$ Transacting means the user utilizes the wallet to create digital information, which expresses the movement of Token from user to the receiver. This transaction is known as Peer-to-Peer ("P2P") exchanges which allows user to exchange directly with one another without having a third party to process their transactions. ${ }^{64}$ Meanwhile, there is also a trading activity in regards to Token, in which the trading platform shall receive trading fees from facilitating the supply and demand. Whereas, the traders are expecting to obtain

60 Ketut Oka Setiawan, above n 48, 130.

61 Dimaz Ankaa Wijaya, Dony Ariadi Suwarsono, above $n$ 25, 4 .

62 Bitcoin.org, Bagaimana cara kerja Bitcoin?, $<$ https://bitcoin.org/id/cara-kerja $>$, Accessed 22 September 2019.

63 Anissa Rahma Diasti, above n 23, 24.

${ }^{64}$ LinkCoin.pro, Peer-to-Peer Exchanges are THE way to Buy \& Sell Cryptocurrency, $<$ https://medium.com/cryptolinks/peer-to-peer- profits from their trading activities in the market. ${ }^{65}$ In Indonesia, the first platform of exchange is called Indodax. ${ }^{66}$ Then according to the explanation of Token transaction and Token trading, it is possible to used Token as a payment method. However, the Indonesian government does not facilitate the use of virtual currency as a legal payment. ${ }^{67}$

Based on the aforementioned, to obtain ownership rights of Token, it can be done through purchasing and transaction as well as trading in the market. Those process could connect to Article 584 of the Civil Code, which from the wording "by appointment or transfer under a civil event to transfer ownership, conducted by a person who was entitled to act freely about the object" it has known that civil event can be in form of agreement, unilateral legal actions or laws, even though the most common are agreements which is the sale and purchase agreement. ${ }^{68}$ Meaning that transacting and trading of Token can also be considered as a civil event that is legal according to the Law.

To elaborate, for the transfer to succeed in making the receiving party to obtain the ownership rights over the goods, the following conditions must be fulfilled:

i. The transfer is based on a civil event

ii. The transfer is conducted by a person who was entitled to act freely towards the object

The first condition, which is the civil event, is a legal relationship that rises obligations to conduct transfer that can be in the form of agreements unilateral legal actions or laws as mentioned above. The obligations shall follow by the action of the transfer. The second condition is regarding the person who conducts the transfer. The person or party who has the authority to conduct the transferring action over the

exchanges-are-the-way-to-buy-sell-

cryptocurrency-a5d6b82ec0e6 $>$, Accessed 22 September 2019.

65 Dimaz Ankaa Wijaya, Dony Ariadi Suwarsono, above n 25, 4 .

66 Dimaz Ankaa Wijaya, Dony Ariadi Suwarsono, above $n$ 25, 6 .

67 Dimaz Ankaa Wijaya, Dony Ariadi Suwarsono, above $n$ 25, 5 .

68 J. Satrio, above n. 50. 
object is the owner of the object in question, although as exceptions, the rights can be in the hands of another person, such as curator, trustees, or bewindvoerder who will act on behalf of the owners. ${ }^{69}$

Hence according to the aforementioned paragraphs, the ways to obtain ownership rights over a property concerning Article 584 of the Civil Code, which in this paper specifically talks about Token, can be done through purchasing and transacting as well as trading. First, purchasing Token is the same with sale and purchase according to the civil event, in which Token can purchase by using the currency. Users can exchange conventional money for online exchange fees in which users buy token using fiat currency on the market and by exchanging for goods or services that accept token through purchasing/transacting. $\quad 70 \quad$ Second, transacting or transaction of Token is the transfer of ownership rights of Token through P2P exchanges between users without the involvement of third parties. Lastly, trading as the transference of Token has conducted in the trading market. Those activities can be legally considered as a civil event as long as it does not violate the law and conducted by the entitled person. Within those activities, the ownership rights of Token could transfer.

\section{Rewarding}

The third way of transferring the ownership rights of the Token is rewarding or gifting. 71 These processes are the processes where the receiver of the reward or gifts obtain Token for free without any expenses. The rewarding or gifting process might happen in several ways, such as gifts from the system to Miner, from becoming a

69 Ibid.

70 Anissa Rahma Diasti, above n 23, 24.

71 Elucidation of Article 8 (2) of PBI 19/2017.

72 Thomas Adams, What is XLM (Stellar Lumens) Cryptocurrency?,

$<$ https://thomasfadams.com/what-is-xlm-stellarlumens-coin/>, Accessed 22 September 2019.

73 Coindesk, What is Stellar? (XLM), $<$ https://www.coindesk.com/information/stellar101-what-is-stellar-xlm>, Accessed 22 September 2019.

74 Yodik Prastya, Mengenal Apa Itu Bounty Hunting Kripto, "bounty hunter", by joining an event made by the system, or by just simply from gift cards. The token can be given for free from the system, in which this happened in 2014, where Stellar network distributed the initial 100 billion of XLM (currency symbol for Stellar) ${ }^{72}$ to a variety of parties consist of individuals who have invited, various parties, Bitcoin holders, and the remaining were kept for the operational purposes. ${ }^{73}$

The fact that prices of cryptocurrency keep increasing in the market makes users harder to purchase it. However, there is a chance to earn free crypto money without spending money, which is through a process called bounty hunting. If translated into activities in the crypto market, companies that introduce products or services will reward bounty hunters after doing their job. ${ }^{74}$ In practice, this activity has associated with an initial coin offering ("ICO"), ICO provides a reward for promoting, bug reporting, or for improving the aspects of the cryptocurrency framework. The reward can be in the form of a Token or fiat currency. ${ }^{75}$ The token can also be given through gift card, which the examples is a Bitcoin Gift Card, that the gift card has used to gifting aspect of cryptocurrency. This gift card allows users to give other people the gift of cryptocurrency without fear and risk. ${ }^{76}$

However, in practice rewarding rarely happens. In Indonesia, Rewarding (hibah) is regulated under Article 1666 of the Civil Code which states that:

"Article 1666 of the Civil Code
Rewarding is an agreement,
whereby the giver, grants the
objects voluntarily and
irrevocably for the benefit of the

$<$ https://www.seputarforex.com/artikel/mengenalapa-itu-bounty-hunting-kripto-284978-38>, Accessed 22 September 2019.

75 Jake Frankenfield, Bounty Programs, $<$ https://www.investopedia.com/terms/b/bountyprograms-ico.asp $>$, Accessed 22 September 2019.

76 Amber Reeves, The Case for Crypto and Gift Cards: Solving the Mistery, $<$ https://reafmarketing.com/the-case-for-cryptoand-gift-cards-solving-the-mystery/>, Accessed 22 September 2019. 
receiver who accepts the transfer of the objects. The law only recognizes rewards between living people."

From the paragraphs above, it could understand that there must be a reason for giving a reward to another person or party. In regards to rewarding Token, the reward mainly given from the system to the user, the difference is only in regards to the purposes, the gifts from the system, for example, the Stellar, aims to increase the attraction towards cryptocurrency specifically the Stellar. Meanwhile, for the bounty hunting associated with ICO, the purpose is mainly to help the ICO and to expand the promotion. In regards to the gift card, the purpose is solely only gifting the cryptocurrency. Concerning Article 1666, Token rewarding or gifting can be considered as rewarding according to the article, whereas Token rewarding happens voluntarily and provides benefits towards the receiver. Therefore, the transfer of ownership rights of Token can also be done through rewarding or gifting.

Therefore, Token could determine as intangible movable property. This is due to Token according to its form, has met the prerequisite characteristics of an intangible property that is digital in its form and having no physical form which interpreted from Article 499 of the Civil Code while according to its movability, Token has considered as movable properties concerning Article 505 which according to its nature Token could move, where the movement is conducted digitally through the blockchain technology. To obtain the ownership rights of Token, with the reference to the elucidation of $\mathrm{BI}$ Regulations, several ways could have conduct that are using the movability of Token, which are: (1) mining; (2) purchasing; or (3) transfer of gifts (rewards).

\section{Capital Market Law}

Without disregarding the possibility of implementing the US regulatory approach in Indonesia, it is important to take into consideration the inherent difference of legal system between the US and Indonesia. While

\footnotetext{
${ }^{77}$ Law Number 8 Year 1995 on Capital Market.
}

the US securities act allows further interpretation through the practice of stare decisis, in Indonesia the attempt to define token as a security or tokenized security can be seen from Law Number 8 the Year 1995 concerning Capital Market (UU Pasmod). ${ }^{77}$ Further, Art. 1(5) of UU Pasmod ${ }^{78}$ defines security as:

"Securities are promissory notes, commercial paper, shares, bonds, evidence of indebtedness, Participation Units of collective investment contracts, futures contracts related to Securities, and all derivatives of securities."

The elucidation further elaborates:

"Derivatives refer to rights that have derived from either debt or equity Securities, such as Options or Warrants. An "Option" is the right to purchase or sell within a certain time, a specified number of Securities at a specified price. A "Warrant" is a Security issued by a company giving the holder the right, six months or more after the Securities are issued, to subscribe to shares of the Company at a specified price."

Tokenized security can fall under the definition of "security" of UU Pasmod assuming that the tokenized security is a security which falls under Art. 1(5).

In regards to discussing the legality of a security token, there are two relevant opinions to be highlighted. Moreover, it is important to emphasize that virtual currency, tokenized security, and security token utilizes the same underlying technology (Blockchain).

According to Soonpeel Edgar Chang, virtual currency does not constitute securities under Art. 1(5) of UU Pasmod (including its elucidation). Regardless of whether the virtual currency is a security or not, some foreign jurisdictions such as the United States, United Kingdom, and Switzerland apply securities regulations to initial coin

\footnotetext{
${ }^{78}$ Article 1(5) of Law Number 8 Year 1995 on Capital Market.
} 
offerings. ${ }^{79}$ ICO (token sale, initial token offering, ITO, or crowd sale) offers existing virtual currency, newly developing virtual currency, or token of certain rights involved in the project to solicit funds from the general public. ${ }^{80}$ South Korea and China, on the other hand, explicitly prohibit ICO as of now.

In Indonesia, there is no explicit prohibition for ICO, however, the current situation is that Indonesia makes it virtually impossible to conduct ICO through banning the use of virtual currencies as payment instruments. ${ }^{81}$ This is also supported by Fahrul S. Yusuf and Harry Kuswara, stating ICO is not yet specifically regulated under UU Pasmod, seeing the status quo. ${ }^{82}$ However, if the issuer uses fiat currency as its payment instrument, it would be allowed in Indonesia. ${ }^{83}$

Such a status quo happened due to the limited definition under UU Pasmod for securities. The status quo of UU Pasmod only defines security as promissory notes, commercial paper, shares, bonds, evidence of indebtedness, Participation Units of collective investment contracts, futures contracts related to Securities, and all derivatives of securities. ${ }^{84}$ However, security token and tokenized security could have classified as a security by analyzing security elements. Referring to H.M.N Purwosutjipto's argument, there were 3 elements which are relevant to determining whether an object could have deemed as a security or not. Therefore, this section will analyze the elements of security on both security token and tokenized security.

79 Finma, Regulatory treatment of ICO \& FINMA Guidance 04/2017 (29/09/2017), FCA, ICO Statements (12/09/2017).

80 Soonpel Edgar Chang, 'Legal Status of Cryptocurrency in Indonesia and Legal Analysis of the Business Activities in Terms of Cryptocurrency', (2019) 6(1) Brawijaya Law Journal: Journal of Legal Studies, 85-86.

81 Article 8, Central Bank of Indonesia Regulation 19/12/PBI/2017

82 Fahrul S. Yusuf and Harry Kuswara, 2018, 'Weighing the Future', International Financial Law Review,

https://www.iflr.com/Article/3821207/Weighingthe-future.html? ArticleId=3821207 $>$ on October 2, 2019.
According to H.M.N Purwosutjipto ${ }^{85}$, promissory notes have three distict elements which are (i) letter of evidence of debt demand, (ii) rights holder, and (iii) transactional.

(i) Letter of Evidence of Debt Demand

The letter has defined as a deed in which it is a letter that is signed and purposely issued to serve as evidence. The signatory is bound by the content within the deed (pacta sunt servanda). $\quad 86$ Consequently, the deed serves as a proof of indebtedness relationship among the signatory. The debt within the deed refers to the fulfillment of agreement by the debtor to the creditor that possesses the right to demand payment as vested by the deed. The demand may be in the form of money (e.g checks), goods (e.g cognossement -bill of lading), or others (e.g charter-party).

(ii) Rights Holder

Rights to demand fulfillment from the debtor. The promissory notes signify the bearer of rights ${ }^{87}$ (Drager van Recht), thus such rights are vested within the deed of promissory notes or seen as inseparable. Consequently, if the deed is missing or destroyed, gone will be the rights to demand fulfillment. "Bearer of rights" is an appealing feature that stands out in:

83 Araya Anggara Putra, Perlindungan Hukum Terhadap Investor Dalam Initial Coin Offering di Indonesia, (Penulisan Hukum, Universitas Gadjah Mada, Yogyakarta, 2018)

84 Article 1(5) of Law Number 8 Year 1995 on Capital Market.

85 H.M.N Purwosutjipto, Pengertian Pokok Hukum Dagang Indonesia: Hukum Surat Berharga, (Djambatan, Jakarta, 1984), 5-6.

86 See further Article 1338 of Indonesia Civil Code (Kitab Undang-undang Hukum Perdata - KUHPer)

87 H.M.N Purwosutjipto, above n. 85, citing "verified by Dorhout Mees, Scheltema/Wiarda, Zevenbergen, and Vollmar on each of their book." 
a) Bank Fiat Money (promes tothe-bearer type promissory notes or promesse aan toonder)

If an IDR10,000 is missing or destroyed, the owner is ineligible to request the Bank of Indonesia for replacement.

b) Draft

If missing, the former owner is ineligible to receive draft payment from the acceptor unless having a guarantee letter equal to the draft's value for 30 years. ${ }^{88}$

c) Surat Sanggup

if missing or destroyed, bound by Art. 176 jo 167 a-b of Indonesia Commercial Code (KUHD). ${ }^{89}$

(iii) Transactional

To enable transaction for a promissory note, it can either have formulated as "to order" (aan order) or "to bearer" (aan toonder). "To order" is transferable via endorsement while "to bearer" via physical. Both have regulated under Art. 613(3) of Indonesia Civil Code. ${ }^{90}$ Moreover, surat yang berharga (papieren van waarde) is solely transferable via cessie as regulated under Art. 613(1-2) of KUHPer. ${ }^{91}$ Therefore, such transfer is quite difficult compared to endorsement or physical.

Based on the aforementioned elements, H.M.N Purwosutjipto further stated that promissory notes could have classified into two types that are "to order" and "to bearer". He concurred with Scheltema/Wiarda's opinion. ${ }^{92}$

If tokenized security falls under the definition of securities as defined by Art.1(5)

88 Article 167a-b of Indonesia Commercial Code (Kitab Undang-undang Hukum Dagang).

89 Article 176 jo $167 \mathrm{a}-\mathrm{b}$ of Indonesia Commercial Code.

90 Article 613(3) of Indonesia Civil Code (KUHPer)

91 Art 613(1-2) of Indonesia Civil Code (KUHPer) of UU Pasmod, then depending on the offering, it can either be offered through IPO procedure as stipulated under UU Pasmod or POJK ECF. ${ }^{93}$ However, in case of security token due to its novel concept, whereas it shares similar traits with conventional securities, through interpreting the notion of "promissory notes" (surat berharga) as mentioned before by H.M.N Purwosutjipto, the security token may be recognized as security under UU Pasmod.

With that in mind thus, it is important to ensure the law not in any way hinders the progress of business practice while, at the same time fulfill the public interest for certainty. As of now in Indonesia, both Indonesia Financial Service Authority (OJK) and Indonesia Commodity Futures Trading Regulatory Agency (BAPPEBTI) have laid down several regulations in regards to crypto products. Particularly for this paper, the regulations that will discuss are related to security token.

Before the discussion of definition and issuance itself, it is important have emphasized that by definition of a security token, OJK and BAPPEBTI have their definition. While for the issuance of security token, it is subject to OJK's regulations. This is to ensure the clarity of the discussion for this section.

Since crypto-assets have deemed as commodity, thus it becomes subject to BAPPEBTI's regulations and terms. According to Art.1(2) of Law Number 10 of 2011 on Commodities \& Futures Trading $(\mathrm{UU} \mathrm{PBK})^{94}$, commodities are any goods, services, rights, and other interest, and every commodity's derivatives, that can be traded and be subject to future contract, sharia derivative contract, and/or another derivative contract. Crypto assets fall under the notion of "rights and other interest".

A more elaborative definition on crypto is stipulated in BAPPEBTI Regulation Number 5 of 2019 on Technicalities of

92 H.M.N Purwosutjipto, above n. 85.

93 OJK Regulation Number 37 Year 2018 on Equity Crowdfunding (POJK 37/2018).

94 Article 1 paragraph (2) Law Number 10 Year 2011 Concerning Futures Trading 
Crypto Asset Trading on Commodities \& Futures Exchange (Reg 5) ${ }^{95}$ as issued by Ministry of Trade Regulation Number 99 of 2018 on General Policy for Commodities \& Futures Trading of Crypto Asset (PERMENDAG 99/2018) ${ }^{96}$. Although Reg 5 regulates trading technicalities, it provides several relevant definitions.

Art. 1(7) of Reg $5^{97}$ defines a crypto asset as an intangible commodity in the form of a digital asset that uses cryptography, peerto-peer network, and distributed ledger (blockchain) for formulating new units, verify transactions, and secure transactions without the need of another party. Moreover Art. 1(13-14) ${ }^{98}$ detailed the definition of token and coin. The coin has defined as one form of crypto asset that possesses its blockchain configuration and possesses characteristics such as the first crypto asset, Bitcoin. The token has defined as one of the crypto assets that derive from the coin. Regardless of BAPPEBTI's attempt to define, in practice coin could betoken and vice versa, depending on the designer/issuer's will.

Art. 3 of Reg 5 stipulates the requirements for a crypto asset to be traded in the exchange. Particularly it allows only either utility crypto or crypto-backed asset. Utility crypto can be for example utility token while the crypto-backed asset is a security token. ${ }^{99}$ Simply put, a utility token is one of the crypto assets where its usage is limited to the ecosystem designed by the issuer. A security token, on the other hand, also known as tokenization is a crypto asset with an underlying asset or object. Such underlying may vary from shares, bonds, part

95 BAPPEBTI Regulation Number 5 of 2019 on Technicalities of Crypto Asset Trading on Commodities \& Futures Exchange

96 Ministry of Trade Regulation Number 99 of 2018 on General Policy for Commodities \& Futures Trading of Crypto Asset

97 Article 1 paragraph (7) BAPPEBTI Regulation Number 5 of 2019 on Technicalities of Crypto Asset Trading on Commodities \& Futures Exchange

98 Article 1 paragraph (14) BAPPEBTI Regulation Number 5 of 2019 on Technicalities of Crypto Asset Trading on Commodities \& Futures Exchange

99 Article 3 paragraph (2) letter b-c BAPPEBTI Regulation Number 5 of 2019 on Technicalities of of the land, etc. depending on the issuer. Moreover, it has clearly stated that Reg 5 has not intended to regulate the initial coin offering (ICO). ${ }^{100}$

OJK possesses the authority over the crypto asset, specifically if its underlying object is share/represents shares ownership. This is due to Art. $1(1 \& 6)$ of Law Number 21 of 2011 on Financial Service Authority (UU OJK) stipulates OJK's regulatory and supervisory functions span to the capital market sector as part of financial service institutions. ${ }^{101}$ The capital market has defined as activities related to Initial Public Offering (IPO) and securities trading, public company related to its issued securities, as well as institutions and professions related to securities as defined by Law Number 8 of 1995 on Capital Market (UU PM). ${ }^{102}$

The aforementioned law applies to shares in general. However, OJK also can regulate security token if such shares are in the scope of Equity Crowd Funding (ECF) as well. This could have seen in Art.35 OJK Regulation Number 37/04 of 2018 on Equity Crowd Funding that stipulates for scriptless trading (non-physical shares) (POJK 37/2018). ${ }^{103}$ Several ECF platforms (i.e. Alumnia and Santara ${ }^{104}$ ) offer the use of blockchain and security token as to ease the ECF scheme. Since security token is similar to scriptless trading, therefore, it can be implied that security token is subject to POJK $37 / 2018$. Having that said, it could have concluded that security token definition can be seen in BAPPEBTI's regulations and to some extent under OJK's regulations.

Crypto Asset Trading on Commodities \& Futures Exchange

100 Ibid., Article 2 paragraph (3)

101 Law Number 21 Year 2011 concerning Financial Services Authority, Article 1 paragraph (1) and (6), Article 4, 5, 8, and 9.

102 Ibid., Article 1 paragraph (6)

103 Article 35 OJK Regulation Number 37/04 of 2018 on Equity Crowd Funding

104 Peter Dabu, 'Santara also conduct crowdfunding for MSMEs through token offering' on Blockchain Media, < <ttps://blockchainmedia.id/santaraklaim-minta-restu-ojk-sebagai-penyelenggaraurun-dana-berbasis-blockchain/>, retrieved October 102019 09.40 AM. 
For the issuance terms specifically for a security token, it has solely regulated by OJK. Assuming if the underlying security token is a security/share the applicable law will be UU PM and POJK 37/2018. Art.1(5) of UU PM defines securities as promissory notes, commercial paper, shares, bonds, evidence of indebtedness, Participation Units of collective investment contracts, futures contracts related to securities, and all derivatives of securities. ${ }^{105}$

POJK $37 / 2018$ is relevant also as it defines ECF as a platform for shares offering by the issuer to the investor through an open electronic system. 106 Taking into consideration that some ECF platforms implement blockchain and usage of security token as a means to deliver non-physical shares. ${ }^{107}$ For security token that has issued in the scheme of ECF, it will be subject to POJK 37/2018. If it has issued by Public Company, hence it is subject to UU PM. Further procedures of shares issuance could have seen in each respective law.

\section{Financial Technology Law}

Issuing token through ICO generally uses virtual currency for payment systems. Post-2016, $80 \%$ of ICOs only accept Bitcoin or Ether as a means of payment. ${ }^{108}$ This is one of the advantages compared to conventional fund collection methods because, with these methods, ICO Organizers can attract Investors from all over the world through the internet network. Payment methods using virtual currency provide convenience and better speed compared to money transfers through banks, so investors are much easier to contribute to ICOs.

In response to the above, in January 2018, Bank Indonesia as the authority of the payment system through Press Release No. 20/4 / Dkom prohibits all payment

105 Undang-undang Nomor 8 Tahun 1995 tentang Pasar Modal, Pasal 1 ayat 5

106 Peraturan OJK Nomor 37 Tahun 2018 tentang Urun Dana Melalui Penawaran Saham Berbasis Teknologi Informasi (ECF), Pasal 1(1)

107 Alumnia \& Sentara

108 Dmitri Boreiko and Navroop K. Sahdev, 'To ICO or not to ICO - Empirical analysis of Initial Coin Offerings and Sales Tokens', (2018) 10 SSRN Electronic Journal, No. 2139/ssrn.3209180, 15. system service Operators and Financial Technology Operators in Indonesia, both Banks and Non-Bank Institutions from processing payment transactions with virtual currency. ${ }^{109}$ Furthermore, positive laws prohibiting the use of virtual currencies are regulated in Bank Indonesia Regulation Number 19/12 / PBI/2017 concerning Implementation of Financial Technology ("PBI 19/2017"). PBI 19/2017 defines Financial Technology in Article 1 number 1 which reads:

"Financial Technology is the use of technology in a financial system that produces new products, services, technology and / or business models and can have an impact on monetary stability, financial system stability, and / or the efficiency, smoothness, security and reliability of payment systems."

Several elements of financial technology can be extracted from the above definition, namely: (1) the use of technology in the financial system; (2) produce new products, services, technology and/or business models; and (3) can have an impact on monetary stability and/or the smooth operation of the payment system. These elements form the basis for an analysis of the status of ICO as a financial technology which has reviewed as follows:

a. The use of technology in the financial system

The financial system is defined as a system that provides an exchange of funds between lenders, investors, and borrowers and operates on a national and global scale. ${ }^{110}$ ICO provides an alternative for investors to invest their capital to businesses through a new asset class, namely tokens. From a technical

${ }^{109}$ Bank Indonesia, Press Release No. 20/4 / Dkom: Bank Indonesia warns all parties not to sell, buy or trade virtual currencies, $<$ https://www.bi.go.id/en/ruang-media/siaranpers/Pages/sp_200418.aspx $>$ accessed 5 April 2018.

110 Arthur O'Sullivan, and Steven M. Sheffrin, Economics: Principles in Action, : Pearson Prentice Hal, (New Jersey, 2003), ISBN 0-13063085-3, 551. 
point of view, ICO uses blockchain technology for publishing tokens. Through the blockchain, investors can send funds and get the proportion of tokens invested.

b. Producing new products, services, technology, and/or business models.

ICO uses blockchain technology that was first popularized by Bitcoin in 2009 . 5 years later, Ethereum was born who brought the concept of crowdfunding to a token 111 above blockchain technology. Although crowdfunding practices have long carried out in Indonesia, ${ }^{112}$ ICO uses a new method of fundraising through blockchain.

c. Having an impact on monetary stability and/or smooth payment system.

If the market capitalization of the ICO continues to increase, it does not rule out the possibility that the ICO can have a widespread impact on financial system stability. Risks in ICO practices have seen in the rise of fraud practices and technological risks that are vulnerable to hacking from outsiders. ${ }^{113}$

Thus, make use of the ICO method in terms of fundraising falls into the category of Financial Technology. ICO Operators are included as Financial Technology Operators in the capital raising category as referred to in Article 3 paragraph (1) letter d PBI $19 / 2017$, which is "every party that carries out Financial Technology activities". This has also emphasized in the Elucidation of Article 3 paragraph (1) letter $\mathrm{d}$, which reads as follows:

Examples of the implementation of Financial Technology in the categories of lending, financing

111 Vitalik Buterin, 'Ethereum White Paper: A NextGeneration Smart Contract and Decentralized Application

Platform', < https://github.com/ethereum/wiki/wik i/White-Paper\#token-systems $>$, accessed 18 October 2019.

112 In Indonesia, crowdfunding practices are quite common. KitaBisa is one of the popular crowdfunding donation-based platforms. Legally, KitaBisa's business model can be included as the practice of collecting money and goods as regulated in Law No. 9 of 1961 concerning the Collection of Money and Goods. See: KitaBisa, "Izin Penggalangan Dana KitaBisa or funding, and capital raising include information technology-based lending and borrowing services (peer-topeer lending) and information technology-based financing or fundraising (crowd-funding).

Departing from the description above, it could have concluded that ICO meets crowdfunding characteristics because ICO uses information technology to mobilize through token and fiat money payments to have exchanged for token issuance.

The legal consequences of the above basis prohibit the Operator from using virtual currency. This condition is certainly in contrast to the ICO payment method, which has generally integrated with blockchain, which generally uses tokens as payment options such as Bitcoin and/or Ether. The prohibition on the use of tokens as a means of payment has regulated in Article 8 paragraph (2) PBI 19/2017 which reads "In addition to the obligations referred to in paragraph (1), Operators of Financial Technology are prohibited from carrying out payment system activities using virtual currencies." what is meant by virtual currency is spelled out in the Explanation of Article 8 paragraph (2) PBI 19/2017 which reads:

What is meant by "virtual currency" is digital money issued by parties other than monetary authorities that are obtained by mining, purchasing, or transfer of gifts (rewards).

Prohibition of carrying out payment system activities using virtual currency because virtual

Permit", https://help.kitabisa.com/articles/360000 376614-whether-kitabisa-have-investingdiscounting-dana, accessed 18 October 2019.

113 On June 17, 2016, one of the ICO projects, Decentralized Autonomous Organization (The DAO) got cyber attacks from hackers. This event eliminated 3.6 million Ether with a potential loss of 50 million US dollars. See: Nathaniel Popper, "A Hacking of More Than \$ 50 Million Dashes Hopes in the World of Virtual Currency", https://www.nytimes.com/2016/06/18/business/de albook/hacker-may-have-removed -more-than-50million-from-experimental-cybercurrencyproject.html, accessed October 10, 2019. 
currency is not a legal payment instrument in Indonesia.

Although the terminology used is a virtual currency, based on the above definition, the token with the payment token classification falls into that definition, which functions like digital money. Tokens are not legal tender in Indonesia. This is stated in Article 1 number 2 of the Law of the Republic of Indonesia Number 7 of 2011 concerning Currency ("Law 7/2011").

The applicable money in

Indonesia has Rupiah as

regulated in Article 2 of Law

7/2011. Based on Article 21

paragraph (1) of Law 7/2011,

Rupiah must have used in every transaction that has the purpose of payment, settlement of other obligations that must have fulfilled with money, and/or other financial transactions conducted in the Territory of the Republic of Indonesia. The exception is that the provisions of Article 21 paragraph (1) are explained in Article 21 paragraph (2).

In addition to Law 7/2011, the obligation to use Rupiah is also regulated in Article 2 of Bank Indonesia Regulation Number 17/3 / PBI / 2015 concerning Rupiah Usage Obligation ("PBI 17/2015"). Furthermore, there is an Operator that violates, then there are administrative sanctions as regulated in Article 18 PBI $17 / 2015$. Whereas violations of the provisions of Article 8 paragraph (2) PBI 19/2017 are regulated in Article 20 paragraph (2) PBI 19/2017. In addition to administrative sanctions, there are criminal sanctions for everyone who violates not using Rupiah as stipulated in Article 33 paragraph (1) of Law 7/2011.

Therefore, if the ICO Operator whose payment system uses payment tokens, this violates the provisions of Article 21 paragraph (1) of Law 7/2011, Article 2 of PBI 17/2015, and Article 8 paragraph (2) of PBI 19/2017.
However, in practice, not all ICOs use payment tokens as their payment system. One example of the implementation of ICO in Indonesia is held by PT Ciptalintang Aji Dana, which conducts ICO by issuing a token named Cyronium. In the ICO, the payment system not only uses payment tokens but also provides a payment system by bank transfer using Rupiah. ${ }^{114}$ So that ICO conducted by PT Ciptalintang Aji Dana does not violate the provisions of the obligation to use Rupiah in the payment system as stipulated in Law 7/2011, PBI 17/2015, and PBI 19/2017.

Based on the description above, it can have concluded that if the ICO Operator uses virtual currency in its payment system, the Operator violates positive law in Indonesia. Meanwhile, if the ICO Operator uses Rupiah in its payment system, the Operator does not violate the obligation to use Rupiah for each transaction in the Territory of the Republic of Indonesia.

\section{CONCLUSION}

With regards to the research results and analysis, the Author finalizes 2 (two) conclusions which have found how other countries regulate blockchain-based tokens within a taxonomy and the legality of blockchain-based tokens in Indonesia.

We conclude that reflecting upon selected countries (United States, Singapore, Switzerland, Japan, and the United Kingdom), the relevant state regulators have uniformity in responding to blockchainbased tokens. The main points are the determination of tokens as securities and their validity as a means of payment in the jurisdiction of their respective countries. This has implications for the birth of 3 (three) types of tokens that have different legal implications in each country, namely: Security Tokens, Payment Tokens, and Utility Tokens. On the other hand, it needs to underline that the country above has a functional approach in dealing with tokens. This is different from the Indonesian arrangement, which chooses a technical

114 Araya Anggara Putra, Legal Protection of Investors in Inital Coin Offering in Indonesia, 
approach to token management by defining tokens as derivatives of coins.

Furthermore, the legality of tokens in Indonesia intersects with several aspects: First, their validity as objects according to the Civil Code; Second, profits from token trading can be subject to Income Tax; Third, there is an overlapping authority in the issue of security token trading between BAPPEBTI and the Financial Services Authority; and Fourth, there is a prohibition on the issuance of tokens through ICO in Indonesia when using the payment token as the payment system.

\section{REFERENCES}

\section{Books}

Narayanan, Arvind, et al., Bitcoin and Cyptocurrency Technologies: A Comprehensive Introduction, (Princeton University Press, Princeton, 2016)

Nian, Lam Pak and David Lee Kuo Chen, 'Introduction to Bitcoin', dalam David Lee Kuo Chen, Handbook of Digital Currency: Bitcoin, Innovation, Financial Instruments and Big Data, (Elsevier Inc., Singapore, 2015)

O'Sullivan, Arthur,and Steven M. Sheffrin, Economics: Principles in Action, : Pearson Prentice Hal, (New Jersey, 2003), ISBN 0-13-063085-3

Purwosutjipto, H.M.N, Pengertian Pokok Hukum Dagang Indonesia: Hukum Surat Berharga, (Djambatan, Jakarta, 1984)

Putra, Araya Anggara, Perlindungan Hukum Terhadap Investor Dalam Initial Coin Offering di Indonesia, (Penulisan Hukum, Universitas Gadjah Mada, Yogyakarta, 2018)

Subekti, Pokok-Pokok Hukum Perdata, (Intermasa, Jakarta, 1984)

Schwab, Klaus, The Fourth Industrial Revolution, (Geneva, World Economic Forum, 2016)

Simanjuntak, P.N.H., Pokok-Pokok Hukum Perdata Indonesia, (Penerbit Djambatan, Jakarta, 1999)

Setiawan, I Ketut Oka, Hukum Perorangan dan Kebendaan, (Sinar Grafika, Jakarta, 2016)
Sofwan, Sri Soedewi Masjchoen, Hukum Perdata: Hukum benda, (Liberty, Yogyakarta, 1981)

Tim Weingärtner, Tokenization of physical assets and the impact of IoT and AI, (Lucerne University of Applied Sciences $\&$ Arts - School for Information Technology, Lucerne).

Usman, Rachmadi, Hukum Hak Atas Kekayaan Intelektual, (PT Alumni, Bandung, 2003)

\section{Journal}

Boreiko, Dmitri and Navroop K. Sahdev, 'To ICO or not to ICO - Empirical analysis of Initial Coin Offerings and Sales Tokens', (2018) 10 SSRN Electronic Journal, No. 2139/ssrn.3209180

Chang, Soonpel Edgar, 'Legal Status of Cryptocurrency in Indonesia and Legal Analysis of the Business Activities in Terms of Cryptocurrency', (2019) 6(1) Brawijaya Law Journal: Journal of Legal Studies, 85-86.

Chen, Yan, 'Blockchain Tokens and The Potential Democratization of Entrepreneurship and Innovation', (2018) 61(4) Business Horizons, $<$ https://doi.org/10.1016/j.bushor.2018. $03.006>$.

Gupta, Suyash \& Sadoghi, Mohammad. (2018). Blockchain Transaction Processing. 10.1007/978-3-319-639628_333-1.

Oliveira, Luis; et al, "To Token or not to Token: Tools for Understanding Blockchain Tokens”, (2018), International Conference of Information Systems

Pilkington, Marc, '11 Blockchain technology: principles and applications.' (2016) 225 Research handbook on digital transformations

World Bank Group, "Distributed Ledger Technology (DLT) and Blockchain", (2017) FinTech Note

Yusuf, Fahrul S. and Harry Kuswara, 2018, 'Weighing the Future', International Financial Law Review, < https://www.iflr.com/Article/3821207/W eighing-the- 
future.html? ArticleId=3821207>

October 2, 2019.

\section{Internet Sources}

Adams, Thomas, What is XLM (Stellar Lumens) Cryptocurrency?, $<$ https://thomasfadams.com/what-isxlm-stellar-lumens-coin/ $>$, Accessed 22 September 2019

Bank Indonesia, Press Release No. 20/4 / Dkom: Bank Indonesia warns all parties not to sell, buy or trade virtual currencies, $<$ https://www.bi.go.id/en/ruangmedia/siaranpers/Pages/sp_200418.aspx $>$ accessed 5 April 2018.

Bitcoin.org, Bagaimana cara kerja Bitcoin?, $<$ https://bitcoin.org/id/cara-kerja $>$, Accessed 22 September 2019

Buterin, Vitalik, Ethereum Whitepaper, $<$ http://blockchainlab.com/pdf/Ethereu m_white_paper-

a next generation smart contract and _decentralized_application_platformvitalik-buterin.pdf.>, accessed April 2 2019.

Buterin, Vitalik, Ethereum White Paper: A Next-Generation Smart Contract and Decentralized Application Platform, <https://github.com/ethereum/ wiki/wiki/White-Paper\#token-systems>, accessed 18 October 2019

Christiani, Theresia Anita, Normative and Empirical Research Methods: Their Usefulness and Relevance in the Study of Law as an Object, (3 ${ }^{\text {rd }}$ Global Conference on Business and Social Sciences-2015, Procedia Social and Behavorial Sciences, Vol. 219, 2016), https:/www.sciencedirect.com/science/ article/pii/S1877042816300660.

Coindesk, What is Stellar? (XLM), $<$ https://www.coindesk.com/information/ stellar-101-what-is-stellar-xlm>, Accessed 22 September 2019.

Dabu, Peter, 'Santara also conduct crowdfunding for MSMEs through token offering' on Blockchain Media, $<$ https://blockchainmedia.id/santaraklaim-minta-restu-ojk-sebagaipenyelenggara-urun-dana-berbasis- blockchain/>, retrieved October 102019 09.40 AM

Deloitte, Breaking blockchain open: Deloitte's 2018 global survey, $<$ https://www2.deloitte.com/content/da $\mathrm{m} /$ Deloitte/us/Documents/financialservices/us-fsi-2018-global-blockchainsurvey-report.pdf. $>$, accessed 1 April 2019.

Ethos, What are Cryptocurrency Miners? How does Cryptocurrency Mining work? https://www.ethos.io/what-are-minerscryptocurrency-mining, Accessed 19 September 2019

Frankenfield, Jake, Bounty Programs, $<$ https://www.investopedia.com/terms/b/ bounty-programs-ico.asp $>$, Accessed 22 September 2019

Financial Conduct Authority United Kingdom, Guidance on Cryptoassets Consultation Paper CP19/3, $<$ https://cdn.crowdfundinsider.com/wpcontent/uploads/2019/01/FCA-

Consultation-Guidance-on-

Cryptoassets-cp19-03.pdf $>$, accessed 2 April 2019

Forrest Stroud, cryptocurrency mining, $<$ https://www.webopedia.com/TERM/C /cryptocurrency-mining.html>,

Accessed 11 Septermber 2019Ito, J., Narula, N. and Ali, R. 'The Blockchain will do to the Financial System What the Internet Did to Media', Harvard Business Review, 2017. $<$ https://hbr.org/2017/03/theblockchain-will-do-to-banks-and-lawfirms-what-the-internet-did-to-media?re ferral $=03758 \& \mathrm{~cm} \_v c=$ rr_item_page.top right $>$, accessed April 22019.

LinkCoin.pro, Peer-to-Peer Exchanges are THE way to Buy \& Sell Cryptocurrency, $<$ https://medium.com/cryptolinks/peerto-peer-exchanges-are-the-way-to-buysell-cryptocurrency-a5d6b82ec0e6>, Accessed 22 September 2019

Merriam-Webster, Defintion of token, $<$ https://www.merriamwebster.com/dictionary/token>, acessed April 32019

Morrissey, Erin, Breaking Down the Blockchain, $<$ https://medium.com/capital-one- 
tech/breaking-down-the-blockchain$\mathrm{f} 4 \mathrm{~b} 87422481 \mathrm{~b}>$, Accessed 2 October 2019

Nakamoto Satoshi, Bitcoin: A Peer-to-Peer Electronic Cash System, $<$ https://bitcoin.org/bitcoin.pdf $>$, accessed April 12019

Prastya, Yodik, Mengenal Apa Itu Bounty Hunting Kripto, $<$ https://www.seputarforex.com/artikel/m engenal-apa-itu-bounty-hunting-kripto284978-38>, Accessed 22 September 2019

Reeves, Amber, The Case for Crypto and Gift Cards: Solving the Mistery, $<$ https://reafmarketing.com/the-case-forcrypto-and-gift-cards-solving-themystery/>, Accessed 22 September 2019

Rosic, Ameer, What is Blockchain Technology? A Step-by-Step Guide for Beginners, $<$ https://blockgeeks.com/guid es/what-is-blockchain-technology/>, Accessed 22 September 2019

Satrio, J., 'Cara untuk Memperoleh Hak Milik Melalui Penyerahan', Hukum Online.com, 1 February 2018, $<$ https://www.hukumonline.com/berita/ baca/lt5a72a1e93c48c/cara-untukmemperoleh-hak-milik-melaluipenyerahan/>

Rexaline, Shanti, Cryptocurrency Mining: What It Is, How It Works And Who's Making Money Off It, $<$ https://m.benzinga.com/article/995362 9>, Accessed $19 \quad$ September 2019TechTerms, Blockchain, $<$ https://techterms.com/definition/block chain>, Accessed 21 September 2019

US Congress, H.R.7356-Token Taxonomy Act,$<$ https://www.congress.gov/bill/115 th-congress/house-bill/7356/text $>$, accessed 1 Apri 2019.

Zīle, Kaspars and Renāte Strazdiņa, 'Blockchain Use Cases and Their Feasibility', (2018) 23(1) De Gruyter Open: Applied Computer Systems, ISSN 2255-8691 (online) ISSN 2255-8683 (print), doi: 10.2478/acss-2018-0002.

\section{Conference}

Christiani, Theresia Anita. 'Normative and Empirical Research Methods: Their
Usefulness and Relevance in the Study of Law as an Object', (3rd Global Conference on Business and Social Sciences-2015) (2016) 219 Procedia Social and Behavorial Sciences, $<$ https://www.sciencedirect.com/science /article/pii/S1877042816300660>

Miscione, Gianluca, et al., "Tribal Governance: The Business of Blockchain Authentication", (2018) 51 $1^{\text {st }}$ Hawaii International Conference on System Sciences ISBN: 978-0-99813311-9 In Proceeding).

Oliveira, Luis, et.al., 'To Token or not to Token: Tools for Understanding Blockchain Tokens', (International Conference of Information Systems (ICIS 2018), San Francisco, USA, 12 December 2018 - 16 December 2018), https://doi.org/10.5167/uzh-157908

\section{Thesis}

Anggara Putra, Araya, Perlindungan Hukum Terhadap Investor dalam Initial Coin Offering (Universitas Gadjah Mada, 2018).

Diasti, Anissa Rahma, The Legal Standing Bitcoin as A Commodity and Chance of Bitcoin as A Commodity Upon Futures Trading in Indonesia, (Universitas Gadjah Mada, 2018)

\section{Law}

Indonesian Civil Code

Law Number 8 Year 1995 on Capital Market

Law Number 7 Year 2011 on Currency

Law Number 10 Year 2011 on Futures Trading

Law Number 21 Year 2011 on Financial Services Authority

BAPPEBTI Regulation Number 5 of 2019 on Technicalities of Crypto Asset Trading on Commodities \& Futures Exchange

Ministry of Trade Regulation Number 99 of 2018 on General Policy for Commodities \& Futures Trading of Crypto Asset

OJK Regulation Number 37/04 of 2018 on Equity Crowd Funding

BI Regulation Number 10/9 of 2017 on Financial Technology 